Original article

\title{
SEROLOGIC SURVEY OF TOXOPLASMA GONDII ANTIBODIES IN CATS (FELIS CATUS) SOLD AT LIVE ANIMAL MARKETS IN SOUTHWESTERN NIGERIA
}

\author{
A. B. AYINMODE ${ }^{1}$, D. O. OLUWAYELU ${ }^{1}$, E. T. BABALOLA ${ }^{2}$ \\ \& M. A. LAWANI ${ }^{3}$ \\ ${ }^{1}$ Department of Veterinary Microbiology and Parasitology, Faculty of Veterinary \\ Medicine, University of Ibadan, Nigeria; ${ }^{2}$ Department of Veterinary Microbiology \\ and Parasitology, Federal University of Agriculture, Abeokuta, Nigeria; ${ }^{3}$ Centre for \\ Control and Prevention of Zoonoses, University of Ibadan, Nigeria
}

\section{Summary}

Ayinmode, A. B., D. O. Oluwayelu, E. T. Babalola \& M. A. Lawani, 2017. Serologic survey of Toxoplasma gondii antibodies in cats (Felis catus) sold at live animal markets in Southwestern Nigeria. Bulg. J. Vet. Med., 20, No 1, 58-64.

Toxoplasma gondii is a zoonotic parasite causing infection in humans and a wide range of mammals, with cats being the final and only host that excrete $T$. gondii-resistant oocysts to the environment. This study was designed to investigate the seroprevalence of antibodies to $T$. gondii in cats sold at Live Animal Markets (LAMs) in Ibadan, Osogbo and Offa, Southwestern Nigeria. Blood samples were randomly collected from 226 cats at these markets and separated sera were tested for the presence of antibodies (IgG) to T. gondii, using two-fold dilutions from 1:20 to 1:320 by the Modified Agglutination Test (MAT). Attributes were analysed using Chi-square and Fisher's exact tests at $\mathrm{P}<0.05$. Median age of cats was 4.0 months (range: $1-36$ months). Of the 226 samples tested, only 10 (4.4\%) were positive for anti-T. gondii IgG antibodies at the cut-off titre of $1: 20$. Nine $(4.0 \%)$ gave a titre of 1:20; one $(0.4 \%)$ gave $1: 80$ while none was positive at 1:40, 1:160 and 1:320 dilutions. Age and gender of cats was not significantly associated with $T$. gondii infection. Our results showed low prevalence of $T$. gondii infection in cats sold at LAMs in studied area and suggests confinement as an efficient way of limiting exposure of cats to infection sources.

Key words: cats, modified agglutination test (MAT), Nigeria, Toxoplasma gondii

\section{INTRODUCTION}

Toxoplasma gondii is a zoonotic parasite that causes infection in humans and a wide range of mammals and birds (Dubey, 2010). T. gondii infection occurs mainly through the consumption of food or water contaminated with sporulated oocysts shed by cats or by consumption of undercooked meat of infected animal containing bradyzoites (Dubey, 1998; 2010). The shedding of resistant oocysts by cats (the only known definitive host) to the environment has been associated with out- 
breaks of disease in humans (Teutsch et al., 1979; Benenson et al., 1982; Bowie et al., 1997; De Moura et al., 2006) and infection through the ingestion of resistant oocysts from environmental sources (water, soil, fruit and vegetables) is thought to have more epidemic consequences than having direct contact with cats (Santos, 2010).

T. gondii infection in cats is usually asymptomatic (Elmore et al., 2010; Bastos et al., 2014), but may occasionally cause non-suppurative encephalomyelitis, pancreatitis and pneumonia-like respiratory disorders. The life cycle of $T$. gondii can be expressed in two phases mainly: a sexual phase occurring in the intestinal epithelium of the cat where oocysts are shed in faeces, and an asexual phase which occurs in the extra-intestinal tissues of mammals and birds (Dubey, 2010). The disease in cats is usually disseminated and more likely to occur when cats consume infected meat and water (Elmore et al., 2010). Clinical infection can also occur when cats are immuno-compromised or suffer from immune-suppressing infections such as feline immunodeficiency virus and feline leukemia virus infections. Symptoms mostly observed in cats infected with $T$. gondii include fever, diarrhoea, icterus, cough, dyspnea, loss of appetite and neurological signs (Elmore $e t$ al., 2010; Bastos et al., 2014).

Serological methods of detecting specific antibodies (IgG or IgM) to T. gondii have been used to investigate the parasite in cats. Methods such as the enzymelinked immunosorbent assay (ELISA), indirect immunofluorescence (IIF), direct agglutination test (DAT) and modified agglutination test (MAT) have been widely used as indicators of exposure to T. gondii (Zarnke et al., 2001; Kikuchi et al., 2004; Mucker et al., 2006; Ayinmode
\& Dubey, 2012). However, the MAT has recently been shown to be a more reliable, sensitive and specific test over the DAT for serological diagnosis of $T$. gondii infections (Dubey, 2010).

$T$. gondii is distributed worldwide and factors such as geographical, environmental and cultural habits have been known to influence the prevalence of the parasite especially in tropical and subtropical regions of the world (Dubey, 2010). Serological studies carried out worldwide indicate varying prevalence rates of $T$. gondii infection with $7 \%$ in Nigeria (Alayande et al., 2012), 57.8\% in China (Qian et al., 2012), 63\% in Albania (Silaghi et al., 2014) and $10 \%-87 \%$ in Brazil (Dubey et al., 2012; Cerro et al., 2014).

In Nigeria, there are many reports on the seroprevalence of Toxoplasma gondii infection in humans and other animals (Uneke et al., 2007; Ishaku et al., 2009; Kamani et al., 2009; Ayinmode \& Dubey, 2012; Ayinmode et al., 2015) but only few studies (Kamani et al., 2010; Alayande et al., 2012) are available on the infection in cats. This study was therefore aimed at investigating the occurrence of antibodies to $T$. gondii in cats sold at markets in southwestern Nigeria.

\section{MATERIALS AND METHODS}

\section{Sampling location}

Samples were randomly collected between January to November 2014 after obtaining necessary permits at cat markets in Ibadan, Oyo state $\left(7^{\circ} 22 \mathrm{~N}, 3^{\circ} 58 \mathrm{E}\right)$, Osogbo, Osun state $\left(7^{\circ} 48 \mathrm{~N}, 4^{\circ} 37 \mathrm{E}\right)$ and Offa, Kwara state $\left(8^{\circ} 13 \mathrm{~N}, 4^{\circ} 42 \mathrm{E}\right)$, Nigeria (Fig. 1) (Blexxonmak, 2010). These markets were situated within the larger community markets; the cats were obtained from both urban and rural areas and were kept and 


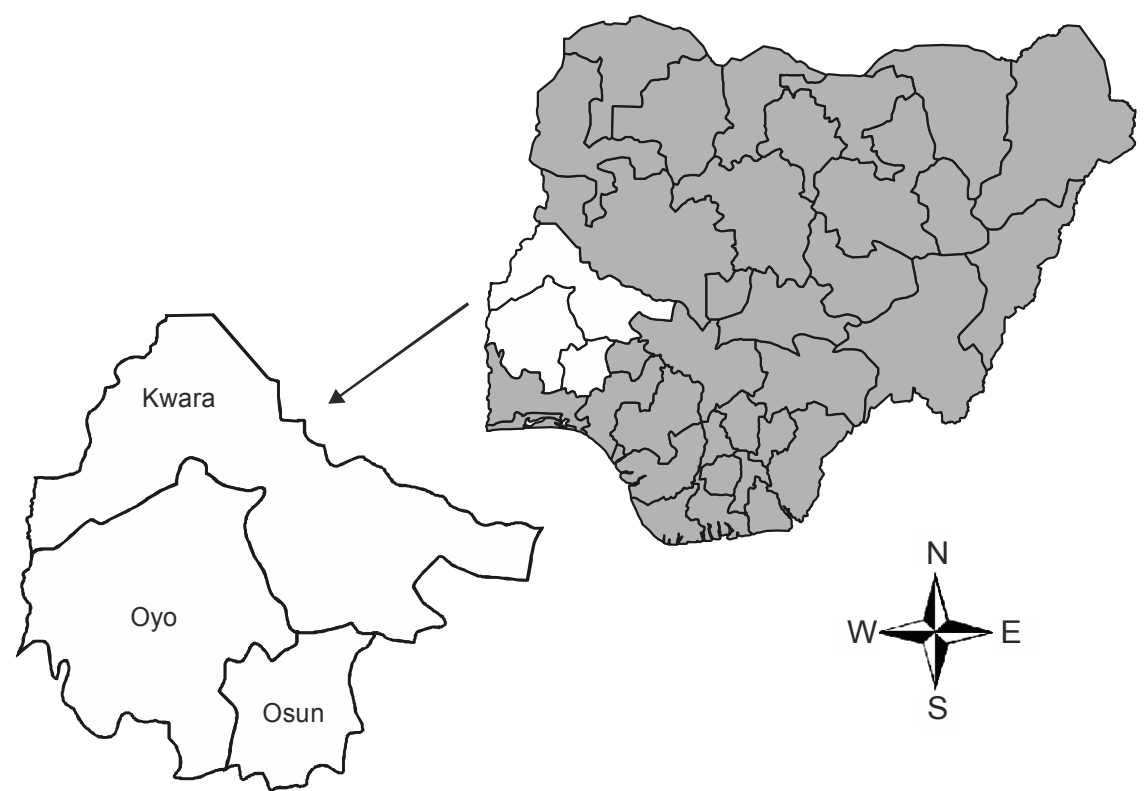

Fig. 1. Map of Nigeria, showing the location of states where cats were sampled.

fed in cages made either of wood or palm fronds till they were sold.

\section{Sampling method}

About $3.0 \mathrm{~mL}$ blood was collected from the saphenous vein of each cat and allowed to clot at room temperature. Sera separated from the samples were then stored at $-20^{\circ} \mathrm{C}$ before being used for serology.

\section{Serological assay}

Sera obtained from the cats were tested for the presence of antibodies (IgG) to $T$. gondii using formalin-killed whole $T$. gondii tachyzoites (RH strain) and twofold dilutions of each serum from 1:20 to $1: 320$ in a modified agglutination test (MAT) as previously described (Dubey, 2010).

\section{Statistical analysis}

Attributes obtained were organised and grouped into quantitative and qualitative variables that were fed into SPSS (version 20) statistical software package (Chicago, IL) for meaningful statistical analysis. Data were then summarised in tables using descriptive and inferential statistics. Categorical variables were reported as frequencies and percentages while continuous variables were examined for skewness, kurtosis and presence of univariate outliers. The continuous variables were reported as median and range for variables not conforming to a normal distribution curve. The concept of relationship that existed between variables was explored using Chi-square analysis and Fisher's exact test at $\mathrm{P}<0.05$. This was done to ascertain the degree of association between categorical variables and the significance of such association.

\section{RESULTS}

A total number of 226 cats were obtained from animal markets in Ibadan (137), Offa 
(46) and Oshogbo (43). The males and females were 112 and 114 respectively. All the cats were local breed and have their sexes intact.The median age of the cats was 4.0 months (range: $1-36$ months) while their mean temperature and median weight was $37.4 \pm 0.976{ }^{\circ} \mathrm{C}$ and $490 \mathrm{~g}$ (range: 200-2100 g) respectively. The majority $(69.9 \%)$ of cats were less than six months of age and only few (8.4\%) were within the 13-36 months age range. Although most $(96.9 \%)$ of the cats were apparently healthy, only few were presented with lice $(2.2 \%)$ and ocular discharges $(0.9 \%)$. Interestingly, none of the cats with visible signs of ill-health (such as lice and ocular discharges) was positive for anti- $T$. gondii IgG antibodies.

Out of the 226 samples collected, only $10(4.4 \%)$ were positive for anti-T. gondii IgG antibodies by MAT at the cut-off titre of 1:20, with 9 samples $(4.0 \%)$ having a titre of $1: 20$, one sample $(0.4 \%)$ having 1:80 titre and no positive sample at 1:40, $1: 160$ and $1: 320$ dilutions.

Comparative analysis between outcome of the infection and explanatory variable revealed that all samples positive for anti-T. gondii IgG antibodies were from cats less than six months of age. Age was however not a statistically significant consideration for $T$. gondii infection.

Table 1. Comparison of anti-Toxoplasma gondii $\operatorname{IgG}$ antibody status with physical characteristics of cats sold in Southwestern Nigerian markets $(n=226)$

\begin{tabular}{|c|c|c|c|c|}
\hline \multirow{2}{*}{ Variable } & \multicolumn{2}{|c|}{ Anti-Toxoplasma IgG antibody } & \multirow{2}{*}{$\chi^{2}$} & \multirow{2}{*}{$P$ value } \\
\hline & Positive (\%) & Negative $(\%)$ & & \\
\hline \multicolumn{5}{|l|}{ Age: } \\
\hline $\begin{array}{l}<6 \text { months (Kittens) } \\
6-12 \text { months (Juvenile) } \\
13-36 \text { months (Young adults) }\end{array}$ & $\begin{array}{c}10(6.3) \\
0(0) \\
0(0) \\
\end{array}$ & $\begin{array}{l}148(93.7) \\
49(100) \\
19(100) \\
\end{array}$ & 4.503 & 0.105 \\
\hline \multicolumn{5}{|l|}{ Gender: } \\
\hline $\begin{array}{l}\text { Male } \\
\text { Female }\end{array}$ & $\begin{array}{l}5(4.5) \\
5(4.4)\end{array}$ & $\begin{array}{l}107(95.5) \\
109(95.6)\end{array}$ & $0.001^{\mathrm{FET}}$ & 1.000 \\
\hline \multicolumn{5}{|l|}{ Temperature: } \\
\hline $\begin{array}{l}\text { Below normal range } \\
\text { Within normal range } \\
\text { Above normal range } \\
\end{array}$ & $\begin{array}{l}2(2.2) \\
8(6.0) \\
0(0) \\
\end{array}$ & $\begin{array}{r}88(97.8) \\
125(94.0) \\
3(100) \\
\end{array}$ & 1.967 & 0.374 \\
\hline \multicolumn{5}{|l|}{ Physical condition: } \\
\hline $\begin{array}{l}\text { Apparently healthy } \\
\text { Ocular discharge } \\
\text { Lice }\end{array}$ & $\begin{array}{c}10(4.6) \\
0(0) \\
0(0) \\
\end{array}$ & $\begin{array}{l}209(95.4) \\
2(100) \\
5(100) \\
\end{array}$ & 0.334 & 0.846 \\
\hline \multicolumn{5}{|l|}{ Location: } \\
\hline $\begin{array}{l}\text { Ibadan } \\
\text { Offa } \\
\text { Osogbo }\end{array}$ & $\begin{array}{l}9(6.6) \\
0(0) \\
1(2.3) \\
\end{array}$ & $\begin{array}{c}128(93.4) \\
46(100) \\
42(97.7) \\
\end{array}$ & 4.068 & 0.131 \\
\hline Total & $10(4.4)$ & $216(95.6)$ & & \\
\hline
\end{tabular}

$\mathrm{FET}=$ Fishers Exact Test. 
Comparison of seropositivity based on gender showed that 5 male $(4.5 \%)$ and 5 female $(4.5 \%)$ cats were positive for antiT. gondii $\operatorname{IgG}$ antibodies, indicating that sex was also of no statistical significance for $T$. gondii infection in the present study (Table 1). Similarly, location from which samples were obtained showed no statistically significant association with outcome of $T$. gondii infection as 9 positive samples were from Ibadan, 1 positive sample was from Osogbo and none was found positive from Offa (Table 1).

\section{DISCUSSION}

The seroprevalence rate of $4.4 \%$ for $T$. gondii antibodies obtained in this study is lower than the $36.2 \%$ (Kamani et al., 2010) and 7.0\% (Alayande et al., 2012) rates reported from previous studies in Nigeria. The differences in seroprevalence could partly be attributed to the fact that most seropositive cats documented in these studies were stray or free-roaming while those sampled in the present study were in confinement (cages) with no information on their living conditions before they were bought. Cats in confinement are likely to have low infection rate because of restricted access to infection sources in the environment.

This study also showed that there was no statistically significant association between gender and $T$. gondii infection in cats. This finding is similar to the report of some previous studies (Gauss et al., 2003; Alayande et al., 2012; Cerro et al., 2014) but contrary to the suggestion that there is the likelihood of higher exposure for the male cat due to its territorial dominance (Smith et al., 1992). Our study revealed that kittens less than six months of age had higher antibodies to $T$. gondii infection than other age groups. This fin- ding differs from the report of Alayande et al. (2012) where cats aged between 6-12 months were the most exposed group. Although no statistically significant association was found between $T$. gondii infection and age, it is likely that the seropositive kittens in the studied population may have acquired the infection from their mothers (vertically). However, more studies are needed to verify the possible role of vertical transmission of $T$. gondii infection in kittens.

Our study showed that cats with physical evidence of ill-health were negative for $T$. gondii antibodies while seropositive ones had body temperatures within normal range. This can be attributed to the fact that $T$. gondii infection in cats has been known to be asymptomatic (Elmore et al., 2010; Bastos et al., 2014) with the cats periodically shedding oocysts during primary infection and in the absence of any form of immune incompetence. The absence of clinical symptoms in seropositive cats in this study might also be attributed to the fact that the IgG-based test used could only detect previous exposure to $T$. gondii and not current infection which an IgM-based assay would detect.

In conclusion, age, gender and locations where cats were sampled from were not significantly associated with $T$. gondii infection in the present study, and infected cats did not show clinical symptoms of the infection. Furthermore, the detection of low prevalence of $T$. gondii infection in the studied population of confined cats may substantiate the fact that confinement is an efficient way of limiting the exposure of cats to infection sources. Cat owners are therefore advised to institute appropriate preventive measures that would, as much as possible, restrict cats from having access to and consuming tissues of infected animals, especially rodents. 


\section{ACKNOWLEDGMENTS}

Our special thanks go to Mr. O.O. Obebe for his technical assistance throughout the project.

\section{REFERENCES}

Alayande, M. O., L. D. Edungbola, J. P. Fabiyi, O. O. Faleke, S. K. Babatunde, A. A. Akanbi II \& A. Nyamngee, 2012. Toxoplasma gondii and intestinal helminth infections among owned and strayed cats in Sokoto, Nigeria, Research Journal of Veterinary Sciences, 5, 69.

Ayinmode, A. B. \& J. P. Dubey, 2012. Toxoplasma gondii infection in Free-range chicken: Mini-review and seroprevalence study in Oyo State, Nigeria. African Journal of Biomedical Research, 15, 145-148.

Ayinmode, A. B., O. O. Ishola \& T. A. Oderinu, 2015. Seroprevalence of Toxoplasma gondii in dogs slaughtered for food in Southwestern Nigeria and assessment of consumer's knowledge and behavior. $\mathrm{Al}$ exandria Journal of Veterinary Science, 45, 161-165.

Bastos, B. F., B. Brener, L. Gershony, L. Willi, N. Labarthe, C. Pereira \& F. Mendes-De-Almeida, 2014. Seroprevalence of Toxoplasma gondii (Nicole \& Manceaux, 1909) and retroviral status of client-owned pet cats (Felis catus, Linnaeus, 1758) in Rio de Janeiro, Brazil, Archive of Revista do Instituto de Medicina Tropical de Sao Paulo, 56, 201-203.

Benenson, M. W., E. T. Takafuji, S. M. Lemon, R. L. Greenup \& A. J. Sulzer, 1982. Oocyst-transmitted toxoplasmosis associated with ingestion of contaminated water. New England Journal of Medicine, 307, 666-669.

Blexxonmak, 2010. Latitudes and Longitudes of major towns in Nigeria. www.nairaland. com/486575/latitudes-longitudes-majortowns-nigeria (Date last accessed $17 \mathrm{De}-$ cember 2015).

Bowie, W. R., A. S. King, D. H. Werker, J. L. Isaac-Renton, A. Bell, S. B. Eng \& S. A.
Marion, 1997. Outbreak of toxoplasmosis associated with municipal drinking water. Lancet, 350, 173-177.

Cerro, L., A. Rubio, R. Pinedo, F. Mendes-deAlmeida, B. Brener \& N. Labarthe, 2014. Seroprevalence of Toxoplasma gondii in cats (Feliscatus, Linnaeus 1758) living in Lima, Peru, Brazilian Journal of Veterinary Parasitology, 23, 90-93.

De Moura, L., L. M. Bahia-Oliveira, M. Y. Wada, J. L. Jones, S. H. Tuboi, E. H. Carmo, W. M. Ramalho, N. J. de Camargo, R. Trevisan, R. M. T. Graça, A. J. da Silva, I. Moura, J. P. Dubey \& D. O. Garrett, 2006. Waterborne toxoplasmosis, Brazil, from field to gene. Emerging Infectious Diseases, 12, 326-329.

Dubey, J. P. \& C. P. Beattie, 1988. Toxoplasmosis of Animals and Man, CRC Press, Boca Raton, FL., pp. 220.

Dubey, J. P., 2010. Toxoplasmosis of Animals and Humans, CRC Press, Boca Raton, FL, pp. 313.

Dubey, J. P., E. G. Lago, S. M. Gennari, C. Su \& J. L. Jones, 2012. Toxoplasmosis in humans and animals in Brazil: High prevalence, high burden of disease and epidemiology. Parasitology, 139, 1375-424.

Elmore, S. A., J. L. Jones, P. A. Conrad, S. Patton, D. S. Lindsay \& J. P. Dubey, 2010. Toxoplasma gondii: Epidemiology, feline clinical aspects, and prevention. Trends in Parasitology, 26, 190-196.

Gauss, C. B. L., S. Almeria, A. Ortuno, F. Garcia \& J. P. Dubey, 2003. Seroprevalence of Toxoplasma gondii antibodies in domestic cats from Barcelona, Spain. Journal of Parasitology, 89, 1067-1068.

Ishaku, B. I. Ajogi, J. U. Umoh, I. Lawal \& A. J. Randawa, 2009. Seroprevalence and risk factors for Toxoplasma gondii infection among antenatal women in Zaria, Nigeria. Research Journal in Medicine and Medical Science, 4, 483-488.

Kamani, J. M., A. U. Mani, H. A. Kumshe, G. I. Dogo, J. P. Yidawi, D. K. Pauline, H. E. Nnabuife, P. Joan \& G. O. Egwu, 2009. Serosurvey for Toxoplasma gondii in dogs 
Serologic survey of Toxoplasma gondii antibodies in cats (Felis catus) sold at live animal markets in...

in Maiduguri, Borno State, Nigeria. The Journal of Infection in Developing Countries, 4, 15-18.

Kamani, J. M., A. U. Kumshe, H. A. Yidawi \& G. O. Egwu, 2010. Prevalence of Toxoplasma gondii antibodies in cats in Maiduguri, Northeastern Nigeria. Acta Parasitologica, 55, 94-95.

Kikuchi, Y., B. B. Chomel, R. W. Kasten, J. S. Martenson, P. K. Swift \& S. J. O'Brien, 2004. Seroprevalence of Toxoplasma gondii in American free-ranging or captive pumas (Felis concolor) and bobcats (Lynx rufus). Veterinary Parasitology, 120, 1-9.

Mucker, E. M., J. P. Dubey, M. J. Lovallo \& J. G. Humphreys, 2006. Seroprevalence of antibodies to Toxoplasma gondii in the Pennsylvania bobcat (Lynx rufus rufus), Journal of Wildlife Diseases, 42,188-191.

Qian, W., H. Wang, C. Su, D. Shan, X. Cui, N. Yang, C. Lv \& Q. Liu, 2012. Isolation and characterization of Toxoplasma gondii strains from cats revealed a single genotype in Beijing China, Veterinary Parasitology, 187, 408-413.

Santos, T. H., C. M. Nunes, M. C. R. Luvizotto, A. B. de Moura, W. D. Lopes, A. J. da Costa \& K. D. Bresciani, 2010. Detection of Toxoplasma gondii oocysts in environmental samples from public schools. Veterinary Parasitololgy, 171, 53-57.

Silaghi, C., M. Knaus, D. Rapti, I. Kusi, E. Shukullari, D. Hamel, K. Pfister \& S. Rehbein, 2014. Survey of Toxoplasma gondii and Neospora caninum, haemotropic mycoplasmas and other arthropod-borne pathogens in cats from Albania, Parasites \& Vectors, 7, 62.
Smith, K. E., J. J. Zimmermoni, S. Patton, C. W. Beron \& H. T. Hill, 1992. The epidemiology of toxoplasmosis in Iowa swine focus with an emphasis on the roles of free living mammals, Veterinary Parasitology, 42, 199-217.

Teutsch, S. M., D. D. Juranek, A. Sulzer, J. P. Dubey \& R. K. Sikes, 1979. Epidemic toxoplasmosis associated with infected cats. New England Journal of Medicine, 300, 695-699.

Uneke, C. J., D. D. Duhlinska, B. A. Ngwu \& M. O. Njoku, 2007. Seroprevalence of Toxoplasma gondii infection in Kwal, a rural distriction of Plateau-Nigeria. African journal of Medicine and Medical Sciences, 36, 109-113.

Zarnke, R. L., J. P. Dubey, J. M. VerHoef, M. E. McNay \& O. C. H. Kwok, 2001. Serologic survey for Toxoplasma gondii in lynx (Felis lynx) from interior Alaska, Journal of Wildlife Diseases, 37, 36-38.

Paper received 14.09.2015; accepted for publication 12.11.2015

\section{Correspondence:}

A. B. Ayinmode Department of Veterinary Microbiology and Parasitology,

Faculty of Veterinary Medicine,

University of Ibadan, Nigeria

e-mail: ayins2000@yahoo.com 